\title{
Associated factors to urinary incontinence in women undergoing urodynamic testing*
}

\author{
Fatores associados à incontinência urinária em mulheres \\ submetidas ao exame urodinâmico \\ Factores asociados con la incontinencia urinaria en mujeres \\ sometidas al estudio urodinámico
}

\section{Juliana Cristina Pereira da Silva ${ }^{1}$, Zaida Aurora Sperli Geraldes Soler ${ }^{1}$, Anneliese Domingues Wysocki ${ }^{2}$}

How to cite this article:

Silva JCP, Soler ZASG, Wysocki AD. Associated factors to urinary incontinence in women undergoing urodynamic testing. Rev Esc Enferm USP. 2017;51:e03209. DOI: http://dx.doi.org/10.1590/S1980-220X2015048003209

* Extracted from the dissertation

"Incontinência Urinária pós-estudo urodinâmico: variáveis associadas”, Programa de Pós-Graduação, Faculdade de Medicina de São José do Rio Preto, 2016.

${ }^{1}$ Faculdade de Medicina de São José do Rio Preto, São José do Rio Preto, SP, Brazil.

${ }^{2}$ Universidade Federal de Mato Grosso do Sul, Três Lagoas, Mato Grosso do Sul, Brazil.

\begin{abstract}
Objective: Analyzing factors associated with urinary incontinence (UI) among women submitted to urodynamic testing. Method: A cross-sectional study of 150 women attended at a urological center. Data were analyzed using univariate and multivariate statistics. Results: White women (79.3\%), overweight (45.3\%), menopausal (53.3\%), who drink coffee $(82.7 \%)$, sedentary $(65.3 \%)$, who had vaginal birth $(51.4 \%)$, with episiotomy (80\%), and who underwent the Kristeller maneuver (69\%). 60.7\% had Urethral Hypermobility (UH). A statistical association was found between: weight change and UH $(p=0.024)$; menopause, Intrinsic Sphincter Deficiency (ISD) and Detrusor Instability (DI) $(p=0.001)$; gynecological surgery, ISD and DI $(p=0.014)$; hysterectomy and all types of UI $(p=0.040)$; physical activity and mixed UI $(p=0.014)$. Conclusion: Interventions and guidance on preventing UI and strengthening pelvic muscles should be directed at women who present weight changes, who are sedentary menopausal women, and those who have undergone hysterectomy or other gynecological surgery. Studies on pelvic strengthening methods are needed in order to take into account the profile of the needs presented by women.
\end{abstract}

\section{DESCRIPTORS}

Urinary incontinence; Risk factors; Urodynamics; Urological Diagnostic Techniques; Women's Health. 


\section{INTRODUCTION}

Urinary incontinence (UI) is defined by the International Continence Society (ICS) as any complaint of urine loss, regardless of the degree of social or hygienic discomfort it causes, and affects $14 \%$ to $57 \%$ of women aged between 20 and 89 years $^{(1-4)}$. Its higher prevalence in women stems from the lower length of the urethra, the anatomy of the pelvic floor, pregnancy and delivery, overcoming hormonal changes throughout their life cycles after ovarian follicle depletion and progressive hypoestrogenism ${ }^{(5-6)}$. In general, the main risk factors for UI are related to sociodemographic aspects, clinical history of certain diseases, gynecological and obstetric factors, as well as life habits; especially smoking, caffeine consumption and sedentary lifestyle or intense physical activity ${ }^{(5-6)}$.

The negative impacts of UI on women stand out in their reports such as: discomfort and embarrassment of losing urine with minimal effort, frequent trips to the bathroom, being wet and ashamed of a urine odor for stretches of time, losing urine on the way to the toilet, restricted time being away from home, having to control fluid intake, as well as family and social relationship problems. By affecting all aspects of their quality of life, such problems generate fear, shame, embarrassment and humiliation, along with physical, emotional, psychological and social consequences ${ }^{(1,3-4)}$.

UI is classified into: Stress urinary incontinence (SUI); Urethral hypermobility (UH); Intrinsic Sphincter Deficiency (ISD); by detrusor hyperactivity or Detrusor muscle instability (DI). In the focus of UI, Urodynamic testing (UDT) is a widely used diagnostic technique in Brazil, done in association with surveying patient's data on circumstances, frequency and severity of urine $\operatorname{loss}^{(7)}$. However, this technique is questioned due to its cost, which impedes it being carried out on a larger scale due to the discomfort and embarrassment of those who are submitted to it, and the fact that it often does not show the reported symptoms such as in cases of overactive bladders ${ }^{(8)}$.

Several studies have been carried out in Brazil regarding UI in women, however studies that address the association between types of UI and their subclassifications are still scarce, which would allow for obtaining subsidies to design diagnostic and treatment measures which can minimize or prevent the presented symptoms occurring, resulting in a better quality of life for women.

Thus, the objective of this study is to analyze the sociodemographic, health, life habits, gynecological antecedents and obstetric factors associated with urinary incontinence among women undergoing urodynamic testing.

\section{METHOD}

This is a cross-sectional quantitative research approved by the Research Ethics Committee of the São José do Rio Preto School of Medicine (FAMERP) under number 303.015, conducted with women with UI treated at a Urological Diagnosis and Treatment Center in the city of São José do Rio Preto. This center attends private patients, those with supplementary health insurance and the Brazilian Unified Health System (Sistema Único de Saúde - SUS), with an average of 100 urodynamic tests conducted on women per month.
The sample consisted of 150 women with UI undergoing urodynamic testing, selected by non-probabilistic convenience sample, and including the first 30 women who performed UDT every month between May and September 2013. Inclusion criteria adopted were: being a woman over the age of 18 , not being in the gestational and puerperal periods, not having cognitive deficit and accepting to participate in the study after orientation on the study and signing of the Informed Consent Form. Those under 18 years of age or unable to read and respond to the questionnaire were excluded.

Data were collected through primary and secondary data sources. Participants responded to an instrument adapted from Higa ${ }^{(5)}$, which included variables related to gynecological history, as well as sociodemographic, obstetric, health data and lifestyle habits. UI classification was performed based on the findings of the urodynamic testing medical report, collected through a review of the participants' medical charts. Thus, UI types were classified into: UI by Detrusor instability (DI) and Stress Urinary Incontinence (SUI), which was then divided into two classifying subgroups according to the cause of UI: SUI by Urethral Hypermobility (UH) and SUI by Intrinsic Sphincter Deficiency (ISD); or Mixed UI (SUI + DI).

Data were analyzed using descriptive, univariate and multivariate statistical techniques. The following tests were performed in order to verify the association between UI types and the studied variables: Chi-square test of association or Fisher's Exact Test where appropriate, and Multiple Correspondence Factorial Analysis. For comparing age and types of UI, the Analysis of Variance test (ANOVA) was used with Tukey's multiple comparison post-hoc test, or Kruskal-Wallis test with a Dunn multiple comparison posthoc test, adopting a significance level of 5\%. Only 10 (6.7\%) women who had no obstetric history were excluded for the obstetric data analysis, thus totaling a sample of 140 women.

\section{RESUITS}

Among the women studied, the age ranged from 18 to 86 years, with a mean of 53.7 years (SD: 13.7 years, median: 53 years), as shown in Table 1: $79.3 \%$ were white; $60.7 \%$ had weight gain in the last 10 years; $30.7 \%$ had arterial hypertension; $11.3 \%$ made use of diuretics; $11.3 \%$ had diabetes; $53.3 \%$ were in menopause; $93.3 \%$ had obstetric history; $82.7 \%$ consumed coffee daily; $6.7 \%$ were smokers and $26 \%$ had been smokers; $26.7 \%$ had a frequent cough; $39.3 \%$ had intestinal constipation; $30.7 \%$ were hysterectomized; $30.7 \%$ underwent perineoplasty; $4.7 \%$ underwent (urethral) sling surgery; $65.3 \%$ were sedentary and $60.7 \%$ presented UI due to Urethral Hypermobility - UH.

Table 2 shows a statistically significant association between the participants' type of UI and weight change, menopause, hysterectomy and physical activity. An association between ISD, DI and mixed UIs was found in postmenopausal women; those who underwent gynecological surgery had ISD and DI types of UI; while those who presented weight change and those who underwent hysterectomy had an association of all types of evaluated UI. Sedentary women had more ISD, UH and DI types of UI, and those who performed physical activity presented more mixed UI. 
Table 1 - Variables of sociodemographic characterization, health and life habits of women submitted to urodynamic testing - São José do Rio Preto, SP, Brazil, May to Sept. 2013.

\begin{tabular}{|c|c|c|c|}
\hline Variables & & $\mathbf{N}$ & $\%$ \\
\hline \multirow{4}{*}{ Race } & Asian & 2 & 1.3 \\
\hline & White & 119 & 79.3 \\
\hline & Black & 7 & 4.7 \\
\hline & Pardo (mixed race Brazilian) & 22 & 14.7 \\
\hline \multirow{3}{*}{ Weight change in the last 10 years } & Has lost weight & 21 & 14.0 \\
\hline & Has gained weight & 91 & 60.7 \\
\hline & Remained the same & 38 & 25.3 \\
\hline \multirow{2}{*}{ Arterial hypertension } & No & 104 & 69.3 \\
\hline & Yes & 46 & 30.7 \\
\hline \multirow{2}{*}{ Use of diuretics } & No & 133 & 88.7 \\
\hline & Yes & 17 & 11.3 \\
\hline \multirow{2}{*}{ Diabetes } & No & 133 & 88.7 \\
\hline & Yes & 17 & 11.3 \\
\hline \multirow{2}{*}{ Menopause } & No & 70 & 46.7 \\
\hline & Yes & 80 & 53.3 \\
\hline \multirow{2}{*}{ Obstetric history } & No & 10 & 6.7 \\
\hline & Yes & 140 & 93.3 \\
\hline \multirow{2}{*}{ Coffee intake } & No & 26 & 17.3 \\
\hline & Yes & 124 & 82.7 \\
\hline \multirow{3}{*}{ Smoker } & No & 101 & 67.3 \\
\hline & Not now, but in the past & 39 & 26.0 \\
\hline & Yes & 10 & 6.7 \\
\hline \multirow{2}{*}{ Frequent cough } & No & 110 & 73.3 \\
\hline & Yes & 40 & 26.7 \\
\hline \multirow{3}{*}{ Constipation } & No & 72 & 48.0 \\
\hline & Not now, but in the past & 19 & 12.7 \\
\hline & Yes & 59 & 39.3 \\
\hline \multirow{2}{*}{ Hysterectomy } & No & 104 & 69.3 \\
\hline & Yes & 46 & 30.7 \\
\hline \multirow{2}{*}{ Perineoplasty } & No & 104 & 69.3 \\
\hline & Yes & 46 & 30.7 \\
\hline \multirow{2}{*}{ Sling (surgery) } & No & 143 & 95.3 \\
\hline & Yes & 7 & 4.7 \\
\hline \multirow{2}{*}{ Physical activity } & No & 98 & 65.3 \\
\hline & Yes & 52 & 34.7 \\
\hline \multirow{4}{*}{ Type of UI } & ISD & 17 & 11.3 \\
\hline & $\cup H$ & 91 & 60.7 \\
\hline & DI & 34 & 22.7 \\
\hline & Mixed & 8 & 5.3 \\
\hline
\end{tabular}

ISD: Intrinsic sphincter deficiency; UH: Urethral Hypermobility; DI: Detrusor hyperactivity or Detrusor instability.

Table 2 - Characterization of women submitted to urodynamic testing according to the type of Urinary Incontinence presented - São José do Rio Preto, SP, Brazil, May to Sept. 2013.

\begin{tabular}{|c|c|c|c|c|c|c|}
\hline \multirow{2}{*}{ Variables } & & \multicolumn{4}{|c|}{ Type of UI } & \multirow{2}{*}{$p$ value } \\
\hline & & ISD & UH & DI & Mixed & \\
\hline \multirow{3}{*}{ Weight change } & Weight loss & $3(17.6 \%)$ & $8(8.8 \%)$ & $6(17.6 \%)$ & $4(50.0 \%)$ & \multirow{3}{*}{0.024} \\
\hline & Weight gain & $8(47.1 \%)$ & $62(68.1 \%)$ & $17(50.00 \%)$ & $4(50.0 \%)$ & \\
\hline & Same & $6(35.3 \%)$ & $21(23.1 \%)$ & $11(32.4 \%)$ & $0(0.0 \%)$ & \\
\hline
\end{tabular}




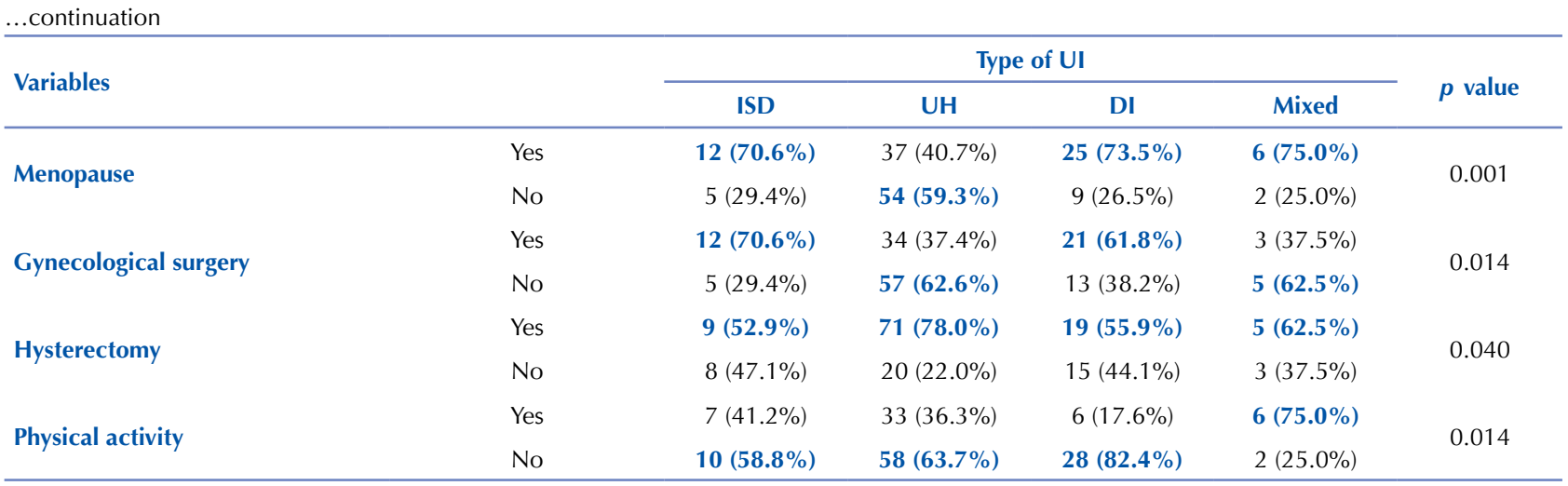

Women with DI type UI were significantly older than those with UH type UI (Table 3).

Figure 1 shows that women with UH type UI were up to 49 years of age, had gained weight in the last 10 years, consumed coffee and had a smoking habit. On the other hand, those with mixed type UI were associated with those in one or more of the following factors: being over 50 years old, overweight, hypertensive, diuretic, diabetic, menopausal and performing some physical activity. Among women with Urinary Incontinence type DI or ISD, disorders such as neurological disease, a cough, constipation and previous gynecological surgery such as hysterectomy, perineoplasty or sling (surgery) have been reported.

Table 3 - Age description of the women submitted to urodynamic testing according to the type of Urinary Incontinence presented São José do Rio Preto, SP, Brazil, May to Sept. 2013.

\begin{tabular}{ccccc}
\hline Type of UI & Mean \pm SD & Median & (Min;Max) & $\boldsymbol{P}_{\text {value }}$ \\
\hline ISD $(\mathrm{n}=17)$ & $57.76 \pm 12.35$ & 58.00 & $(36.0 ; 78.0)$ & $(31.0 ; 79.0)$ \\
UH $(\mathrm{n}=91)$ & $50.35 \pm 11.43$ & 48.00 & $(28.0 ; 86.0)$ & $\mathbf{0 . 0 0 1}$ \\
DI $(\mathrm{n}=34)$ & $59.21 \pm 16.26$ & 60.00 & $(47.0 ; 71.0)$ & \\
Mixed $(\mathrm{n}=8)$ & $59.88 \pm 9.73$ & 62.50 & & \\
\hline
\end{tabular}

${ }^{1} \mathrm{P}$ value for the Analysis of Variance test (ANOVA).

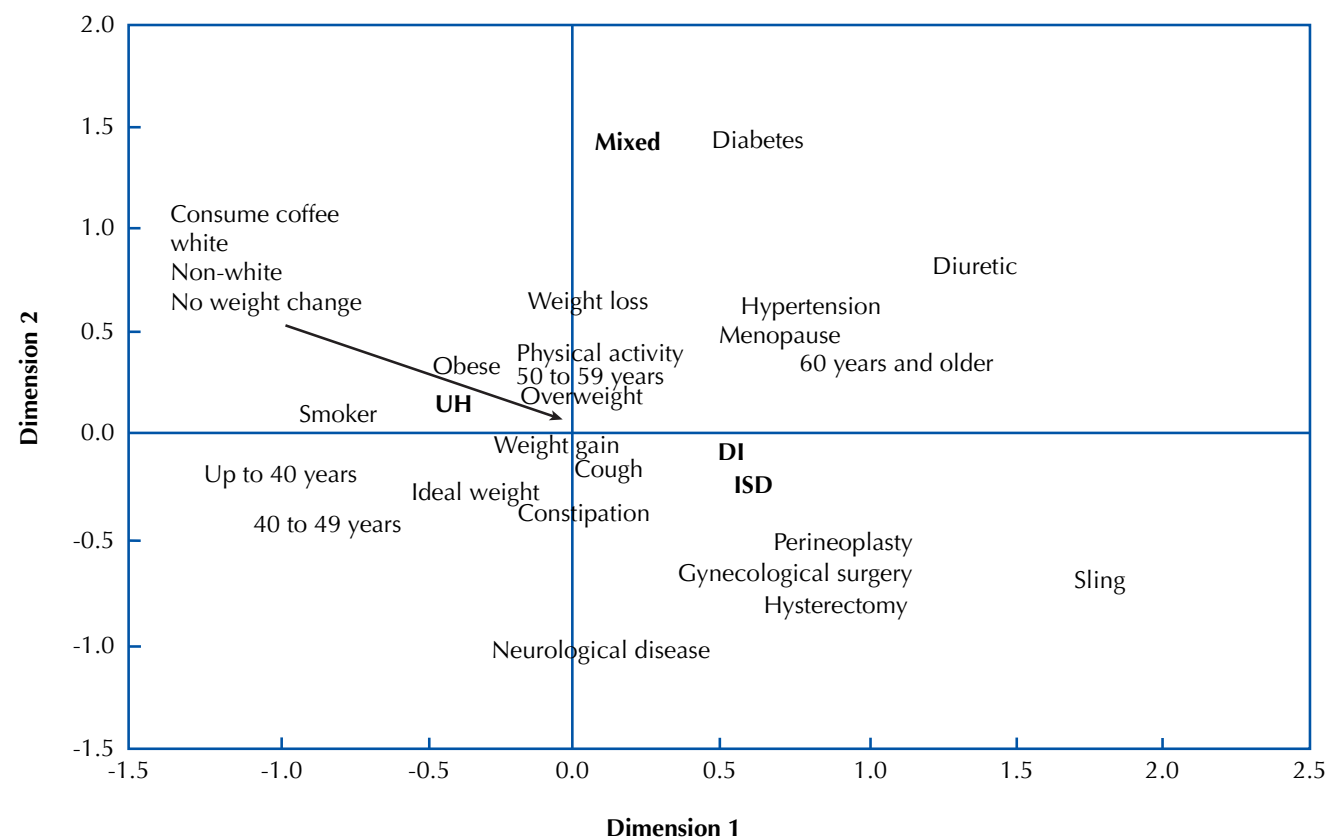

Figure 1 - Factorial analysis of the urinary incontinence types and sociodemographic, obstetric, health and lifestyle variables - São José do Rio Preto, SP, Brazil, May to Sept. 2013.

Table 4 shows descriptions of the obstetric variables and the UI type among the 140 women in the study, showing: mean of 2.8 gestations (SD: 1.5 , minimum 1 and maximum
12 pregnancies); which occurred when the women were 27.4 years old (SD: 5 years); they gained an average of $15.4 \mathrm{~kg}$ (SD: 5.8 , minimum 5 and maximum $30 \mathrm{~kg}$ ); newborns 
weighed an average of $3,480 \mathrm{~g}$ (SD: $535 \mathrm{~g}$ : minimum 1,980 and maximum 5,300g); $48.6 \%$ had an average of 2 cesarean delivery (SD: 0.7, minimum 1 and maximum 3 deliveries); $40(28.6 \%)$ had performed an average of 2.5 vaginal delivery (SD: 1.5 , minimum 1 and maximum 8 deliveries), and 32 (22.9\%) had experienced both types of delivery; 50 (69.4\%) reported that they had undergone Kristeller's maneuver; 58 (80.6\%) had an episiotomy, and 57 (79.2\%) did not use oxytocin. Regarding the type of delivery and UI, we found: ISD (15 - 10.7\%) with 53.3\% cesarean delivery; UH (88$62.9 \%)$; DI type $(29-20.7 \%)$ with $62.1 \%$ vaginal delivery, and mixed UI (8-8.7\%) with $75 \%$ vaginal delivery.

Table 4 - Obstetric variables of women submitted to urodynamic testing according to the type of urinary incontinence presented São José do Rio Preto, SP, Brazil, May to September, 2013.

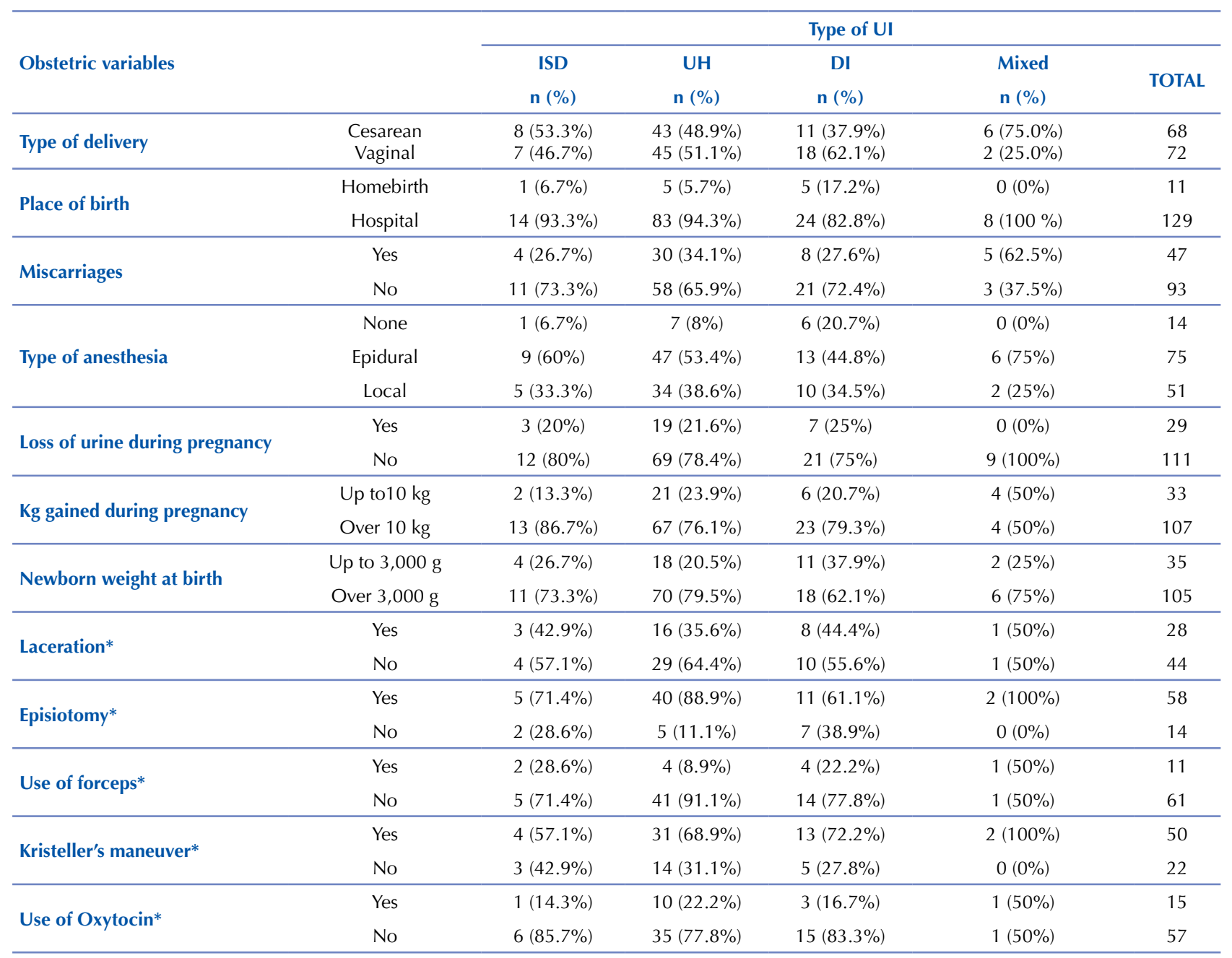

*Only the 72 women who had vaginal delivery were considered for these variables.

\section{DISCUSSION}

Studying the loss of urinary continence and associated factors is not only important because it represents a serious public health problem, but also because of the magnitude of suffering it causes to people affected in the physical, psychological and social spheres ${ }^{(1,9)}$.

The age of women affected by UI is revealed in several studies, showing that UI affects women across a wide age group, especially after the age of 40 , with increasing incidence over the course of aging, as also evidenced in this study. In older adults, the most common type of UI is SUI, with loss of urine when coughing and sneezing ${ }^{(9)}$; followed by DI, characterized by loss of urine before reaching the bathroom $^{(6-11)}$. SUI affects $50 \%$ of North American women, mainly women from the younger age group ${ }^{(11-12)}$.
With regard to ethnicity, there is evidence of higher UI prevalence in white women over the different age groups ${ }^{(13)}$. Although a higher proportion of UI in white women was also identified in the present study, there is no sufficient statistical evidence to support this finding, suggesting that such an outcome may have been influenced by the predominance of the white race in the region studied.

Weight gain is associated with UI, which was also verified in this study, where body mass index (BMI) was determinant of incidence and persistence of $\mathrm{UI}^{(5,14-15)}$. Being overweight among older women contributes to the increase in UI symptoms, evidencing that regular physical exercise is a protective factor against UI, as it prevents obesity ${ }^{(12)}$. In this study, we observed that the majority (of the participants) did not practice physical activity, which may justify the association 
between all types of UI studied and women who reported gaining weight. Studies highlight the importance of physical activity for health, as well as for UI improvement, showing a higher frequency of urinary losses among less active older women ${ }^{(7)}$. On the other hand, practicing rigorous highimpact physical exercise may be a predisposing factor for the development of UI in young and nulliparous women due to the increase in intra-abdominal pressure, as evidenced in women practicing jump classes ${ }^{(16)}$. Although the present study did not measure the strength and the impact of physical exercises performed by the analyzed women, they showed a higher frequency of mixed UI. Given the importance of physical exercise and its effectiveness in treating obesity and presented as an aspect associated with UI, the need for studies with adequate design to evaluate the appearance and severity of UI according to the physical exercise profile is apparent in order to obtain subsidies for implementing specific protective measures to the exercises practiced.

Daily intake of coffee is cited as a factor for UI because caffeine can generate detrusor instability, which leads to loss of urine and a sense of voiding urgency ${ }^{(6)}$. In the present study, $82.7 \%$ of the women reported drinking coffee daily, with an average of 2.5 cups per day (SD: 2.3 cups/day and a median of 2 cups) and between 1.0 and 15.0 cups per day.

Smoking is also associated with loss of urine as tobacco leads to estrogen deficiency and smoking causes frequent coughing, facts that can lead to $\mathrm{UI}^{(6)}$. Although this study found no association between UI and intestinal constipation, some studies show its association with SUI due to the injuries it can cause to the pelvic muscles from the force/ pressure performed during evacuation ${ }^{(6,17)}$.

The association between UI and health problems is reported in several studies. The proportion of women with $\mathrm{UI}$ and hypertension found in this study corresponded to another study that showed the prevalence of UI in women who used diuretics (21.4\%) ${ }^{(15)}$. A 2.5-fold higher association of UI among diabetics is also described, since hyperglycemia causes changes in the muscle and urethral extracellular matrix ${ }^{(18-19)}$.

Gynecological aspects associated with UI were: menopause, explained by the hormonal changes that affect the pelvic muscles ${ }^{(15,20)}$; perineoplasty and sling, which although presenting protective treatments to the appearance of UI, were ineffective among the women in the study; and hysterectomy, referred to as UI risk, as it may cause damage to the structures supporting the bladder and urethra ${ }^{(5,11,21)}$.

UI can be frequent in the gestational period due to the action of increasing uterine pressure and fetal weight on the pelvic floor muscles, and hormonal changes leading to a reduction in the strength of the urethral sphincter support function ${ }^{(20,22)}$. In our study, $21 \%$ of women reported UI during pregnancy. This is a lower proportion than that found in the literature which reveals that lifestyle may have had an influence and that protective measures against the appearance of UI may have been employed even before being pregnant ${ }^{(23-24)}$. A relationship between UI in pregnancy and weight gain of pregnant women has been reported as a risk factor for pelvic floor muscle dysfunction ${ }^{(25)}$. A postpartum strategy for UI prevention is pelvic floor muscle training and postpartum weight loss ${ }^{(26)}$. It is also known that certain symptoms such as frequency, nocturia and urge incontinence (common in pregnancy) decrease significantly and tend to disappear in the postpartum period ${ }^{(25)}$. Parity has been reported as a risk factor for $\mathrm{UI}^{(25-27)}$, which was also demonstrated in this study.

Regarding the history of abortion/miscarriage in women affected by UI, there are few studies that associate this occurrence with the appearance of UI. In the present study we found that the majority of women with UI did not have a history of abortion/miscarriage ${ }^{(22)}$.

Regarding the type of delivery, it is common to assert that vaginal delivery confers a higher risk to the development of SUI in comparison to Cesarean childbirth, thus suggesting that traumas in the pelvic floor from vaginal delivery would represent a risk for development of UI. However, there is scientific evidence that indicates that well-conducted vaginal delivery is more beneficial to both mother and baby. The literature indicates equality in the prevalence of UI among women who had vaginal delivery and those with Cesarean section, reporting an even higher proportion of UI among women who only underwent Cesarean section ${ }^{(24-27)}$. The frequency of UI in women who had vaginal delivery or Cesarean section in the present study was similar.

It was not found that the use of forceps was determinant for UI, although it is mentioned that the use of forceps during vaginal delivery causes more vulvoperineal laceration associated with the appearance of UI, especially SUI. We emphasize that a misuse of forceps is associated to pelvic floor dysfunctions, leading to the appearance of $\mathrm{UI}^{(17,28-30)}$.

Epidural analgesia is cited as a risk factor for UI as it causes prolongation of the expulsive period, increasing the risk of pelvic floor injury. However, some authors consider that such anesthesia protects against UI by inducing relaxation of the pelvic floor musculature, preventing trauma during the expulsive period of vaginal delivery ${ }^{(5)}$. In this study, epidural was responsible for resolving the delivery for the majority of women.

It is recognized that heavier infants cause damage to the pelvic floor muscles, reducing the strength of the sphincter support function, which may cause mobility of the urethra and lead to incompetence of the urethral sphincter and UI. In the present study, the majority of the women had babies weighing more than $3,000 \mathrm{~g}^{(1,25,30)}$.

Many complications can be reduced or prevented with appropriate obstetric care, but in Brazil, and especially in the region of São José do Rio Preto, obstetric care is exceedingly interventionist, technocratic, medicalized and hospitalcentric, resulting in owning the dishonorable title of being the world champion of caesarean sections. Common practices that undermine obstetrical care include inadequate use of oxytocin, lithotomy position at delivery, the Kristeller's maneuver, and inadequate labor guidance procedures ${ }^{(30)}$.

The cooperation of women who provided detailed information on the variables important for this study and the access to participants' medical records can be mentioned as facilities for conducting this research. As difficulties, we can point out the longer time spent in data collection due to 
repeated requests of explanations on the researched subject. Even so, we consider that this research can contribute to deepening knowledge about UI and its associated factors.

\section{CONCLUSION}

The profile of the women participating in this study suggests that prevention and control of UI should be implemented through guidelines on the impact of lifestyle modifications, better control of health problems, and pelvic floor muscle strengthening practices.

Health education practices to prevent the onset of UI should be targeted for all women and can not only be carried out in primary care services, but also in private and specialized institutions/clinics.
Several studies have been carried out in Brazil regarding UI in women, however studies that address the association between types of UI and their subclassifications are still scarce. These would allow for obtaining support in designing diagnostic and treatment measures that can minimize or prevent the appearance of presented symptoms.

Data obtained in this study can provide better professional performance, especially for nurses in establishing care protocols that facilitate diagnosis, and intervention measures for prevention, treatment and control. The investigation field of UI (in women) is wide and necessary for leading to proposals and interventions which prevent and control UI disorders and improve the quality of life of affected women.

\section{RESUMO}

Objetivo: Analisar os fatores associados à Incontinência Urinária (IU) entre mulheres submetidas a estudo urodinâmico. Método: Estudo transversal realizado com 150 mulheres atendidas em um centro urológico. Os dados foram analisados por meio de estatística uni e multivariada. Resultados: Mulheres brancas $(79,3 \%)$, com sobrepeso (45,3\%), na menopausa $(53,3 \%)$, que ingeriam café $(82,7 \%)$, sedentárias (65,3\%), que fizeram parto normal (51,4\%), com episiotomia (80\%), que sofreram Manobra de Kristeller (69\%). 60,7\% apresentavam Hipermobilidade Uretral (HU). Houve associação estatística entre: mudança de peso e HU $(p=0,024)$; menopausa, Deficiência Esfincteriana Intrínseca (DEI) e Instabilidade Detrusora (ID) $(p=0,001)$; cirurgia ginecológica, DEI e ID $(p=0,014)$; histerectomia e todos os tipos de IU $(p=0,040)$; realização de atividade física e IU mista $(p=0,014)$. Conclusão: Intervenções e orientações quanto à prevenção da IU e ao fortalecimento da musculatura pélvica devem ser voltadas a mulheres que apresentam mudança de peso, sedentárias, que se encontram na menopausa e àquelas que realizaram histerectomia ou outra cirurgia ginecológica. São necessários estudos sobre métodos de fortalecimento pélvico, de modo a contemplar o perfil das necessidades apresentadas pelas mulheres.

\section{DESCRITORES}

Incontinência Urinária; Fatores de Risco; Urodinâmica; Técnicas de Diagnóstico Urológico; Saúde da Mulher.

\section{RESUMEN}

Objetivo: Analizar los factores asociados con la Incontinencia Urinaria (IU) entre mujeres sometidas al estudio urodinámico. Método: Estudio transversal llevado a cabo con 150 mujeres atendidas en un centro urológico. Los datos fueron analizados por medio de estadística uni y multivariada. Resultados: Mujeres blancas (79,3\%), con sobrepeso (45,3\%), en la menopausia (53,3\%), que ingerían café $(82,7 \%)$, sedentarias $(65,3 \%)$, que tuvieron parto normal $(51,4 \%)$, con episiotomía (80\%), que sufrieron Maniobra de Kristeller (69\%), el 60,7\% presentaban Hipermovilidad Uretral (HU). Hubo asociación estadística entre: cambio de peso e HU $(p=0,024)$; menopausia, Deficiencia Intrínseca del Esfínter (DIE) e Inestabilidad del Detrusor (ID) $(p=0,001)$; cirugía ginecológica, DIE e ID $(p=0,014)$; histerectomía y todos los tipos de IU ( $p=0,040)$; realización de actividad física e IU mixta $(p=0,014)$. Conclusión: Intervenciones y orientaciones en cuanto a la prevención de la IU y al fortalecimiento de la musculatura pélvica deben dirigirse a mujeres que presentan cambio de peso, sedentarias, que se hallan en la menopausia y las que realizaron histerectomía u otra cirugía ginecológica. Son necesarios estudios sobre métodos de fortalecimiento pélvico, de modo a contemplar el perfil de las necesidades presentadas por las mujeres.

\section{DESCRIPTORES}

Incontinencia Urinaria; Factores de Riesgo; Urodinámica; Técnicas de Diagnóstico Urológico; Salud de la Mujer

\section{REFERENCES}

1. Rincon AA. Caracterización clínica de la incontinencia urinaria y factores asociados en usuarias de la Unidad de la Mujer del Centro de Salud Familiar "Ultraestación" en la ciudad de Chillán, Chile. Rev Med Chile [Internet]. 2015 [citado 2015 nov. 10];143(2):203-12. Disponible en: http://www.scielo.cl/pdf/rmc/v143n2/art08.pdf

2. Bonfim IQM, Soutinho RSR, Araujo EN. Comparação da qualidade de vida das mulheres com incontinência urinária atendidas no sistema de saúde público e privado. UNOPAR Cient Ciênc Biol Saúde [Internet]. 2014 [citado 2015 nov. 10]; 16(1):19-24. Disponível em: http:// www.pgsskroton.com.br/seer/index.php/JHealthSci/article/view/535/504

3. Pedro AF, Ribeiro J, Soler ZASG, Bugdan AP. Qualidade de vida de mulheres com incontinência urinária. SMAD Rev Eletr Saúde Mental Álcool Drog [Internet] 2011 [citado 2015 nov. 10];7(2):63-70 Disponível em: http://www.revistas.usp.br/smad/article/view/49574

4. Senra C, Pereira GM. Quality of life in women with urinary incontinence. Rev Assoc Med Bras [Internet]. 2015 [citado 2015 nov. 11];61(2):178-83. Disponível em: http://www.scielo.br/pdf/ramb/v61n2/0104-4230-ramb-61-02-0178.pdf

5. Higa R, Lopes MHBM, Reis MJ. Fatores de risco para incontinência urinária na mulher. Rev Esc Enferm USP [Internet]. 2008 [citado 2015 nov. 11];42(1):187-92. Disponível em: http://www.scielo.br/pdf/reeusp/v42n1/25.pdf 
6. Marques LP, Schneider IJC, Giehl MWC, Antes DL, d'Orsi E. Fatores demográficos, condições de saúde e hábitos de vida associados à incontinência urinária em idosos de Florianópolis, Santa Catarina. Rev Bras Epidemiol [Internet]. 2015 [citado 2015 nov. 11];18(3):595606. Disponível em: http://www.scielosp.org/pdf/rbepid/v18n3/pt_1415-790X-rbepid-18-03-00595.pdf

7. Monteiro MVC, Fonseca AMRM, Filho ALS. Valor do estudo urodinâmico no tratamento da incontinência urinária. Femina. 2012;40(3):135-9.

8. Virtuoso JF, Mazo GZ, Menezes EC. Prevalência, tipologia e sintomas de gravidade da incontinência urinária em mulheres idosas segundo a prática de atividade física. Fisioter Mov [Internet]. 2012 [citado 2015 nov. 11];25(3):571-82. Disponível em: http://www.scielo.br/pdf/ $\mathrm{fm} / \mathrm{v} 25 \mathrm{n} 3 / 13 . \mathrm{pdf}$

9. Jerez-Roig J, Souza DLB, Lima KC. Incontinência Urinária em idosos institucionalizados no Brasil: uma revisão integrativa. Rev Bras Geriatr Gerontol. 2013;16(4):865-79.

10. Silva VA, D'Elboux MJ. Fatores associados à incontinência urinária em idosos com critérios de fragilidade. Texto Contexto Enferm [Internet]. 2012 [citado 2015 nov. 11]21(2):338-47. Disponível em: http://www.scielo.br/pdf/tce/v21n2/a11v21n2.pdf

11. Delarmelindo RCA, Parada CMGL, Rodrigues RAP, Bocchi SCM. Women's strategies for coping with urinary incontinence. Rev Esc Enferm USP [Internet]. 2013 [cited 2015 Nov 11];47(2):296-302. Available from: http://www.scielo.br/pdf/reeusp/v47n2/en_04.pdf

12. Patrizzi LJ, Viana DA, Silva LMA, Pegorari MS. Incontinência urinária em mulheres jovens praticantes de exercício físico. Rev Bras Ci Mov. 2014;22(3): 105-10.

13. Leroy LS, Lopes MHBN, Shimo AKK.A Incontinência urinária em mulheres e os aspectos raciais: uma revisão de literatura. Texto Contexto Enferm [Internet] 2012 [citado 2015 nov. 11];21(3):692-701. Disponível em: http://www.scielo.br/pdf/tce/v21n3/v21n3a26.pdf

14. Herrmann V, Di Sessa RGDG, Ricceto CLZ, Morais SS, Castro EB, Juliato CR. Associação entre o escore do International Consultationon Incontinence Questionaire: UrinaryIncontinence/Short Form e a Avaliação Urodinâmica em mulheres com incontinência urinária. Rev Bras Ginecol Obstet [Internet]. 2013 [citado 2015 nov. 11];35(1):16-20. Disponível em: http://www.scielo.br/pdf/rbgo/v35n1/04.pdf

15. Berlezi EM, Fiorin AAM, Bilibio PVF, Kirchner RM, Oliveira KR. Estudo da incontinência urinária em mulheres climatéricas usuárias e não usuárias de medicação anti-hipertensiva. Rev Bras Geriatr Gerontol. 2011;14(3):415-23.

16. Almeida PP, Machado LRG. A prevalência de incontinência urinária em mulheres praticantes de jump. Fisioter Mov. 2012;25(1):55-65.

17. Perera J, Kirthinanda DS, Wijeratne S, Wickramarachchi TK. Descriptive cross sectional study on prevalence, perceptions, predisposing factors and health seeking behavior of women with stress urinary incontinence. BMC Womens Health [Internet]. 2014 [cited 2015 Nov 11];14:78. Available from: https://www.ncbi.nlm.nih.gov/pmc/articles/PMC4094634/

18. Oliveira EG, Marinheiro LPF, Silva KS. Diabetes melito como fator associado às disfunções do trato urinário inferior em mulheres atendidas em serviço de referência. Rev Bras Ginecol Obstet. 2011;33(12):414-20.

19. Marini G, Rinaldi JC, Damasceno DC, Felisbino SL, Rudge MVC. Alterações da matriz extracelular causadas pelo diabetes: o impacto sobre a continência urinária. Rev Bras Ginecol Obstet. 2014;36(7):328-33.

20. Sacomori C, Negri NB, Cardoso FL. Incontinência urinária em mulheres que buscam exame preventivo de câncer de colo uterino: fatores sociodemográficos e comportamentais. Cad Saúde Pública [Internet].2013 [citado 2015 nov. 11];29(6): 1251-9. Disponível em: http:// www.scielo.br/pdf/csp/v29n6/a21v29n6.pdf

21. Gomes GV, Silva GD. Incontinência urinária de esforço em mulheres pertencentes ao programa de saúde da família de Dourados (MS). Rev Assoc Med Bras [Internet] 2010 [citado 2015 nov. 11];56(6):649-54. Disponível em: http://www.scielo.br/pdf/ramb/v56n6/v56n6a11.pdf

22. Sangsawang B. Risk factors for the development of stress urinary incontinence during pregnancy in primigravidae: a review of the literature. Eur J Obstet Ginecol Reprod Biol. 2014;178:27-34.

23. Riesco MLG, Fernandes-Trevisan K, Leister N, Cruz CS, Caroci AS, Zanetti MRD. Urinary incontinence related to perineal muscle strength in the first trimester of pregnancy: cross-sectional study. Rev Esc Enferm USP [Internet]. 2014 [cited 2015 Nov 11];48(n.spe):32-8. Available from: http://www.scielo.br/pdf/reeusp/v48nspe/0080-6234-reeusp-48-esp-033.pdf

24. Barbosa AMP, Marini G, Piculo F, Rudge CVC, Calderon IMP, Rudge MVC. Prevalence of urinary incontinence and pelvic floor muscle dysfunction in primiparae two years after cesarean section: cross-sectional study. São Paulo Med J. 2013;131(2):95-9.

25. Botelho S, Silva JM, Palma P, Herrmann V, Riccetto C. Can the delivery method influence lower urinary tract symptoms triggered by the first pregnancy? In. Braz J Urol. 2012;38(2):267-76.

26. Svare JA, Hansen BB, Lose G. Risk factors for urinary incontinence 1 year after the first vaginal delivery in a cohort of primiparous Danish women. Int Urogynecol. 2014;25(1):47-51.

27. Leroy LS, Lopes MHBM. Urinary incontinence in the puerperium and its impact on the health-related quality of life. Rev Latino Am Enfermagem [Internet]. 2012 [cited 2015 Nov 11];20(2):346-53. Available from: http://www.scielo.br/pdf/rlae/v20n2/18.pdf

28. Handa VL, Blomquist JL, McDermott KC, Friedman S, Muñoz A. Pelvic floor disorders after childbirth: effect of episiotomy, perineal laceration, and operative birth. Obstet Gynecol. 2012;119(2 Pt 1):233-9.

29. Lima MC, Moccelin GBA, Silva MB, Nogueira GB. Effect of mode of delivery and parities on the occurrence of urinary incontinence during pregnancy. Fisioter Mov. 2015;28(1):107-16.

30. Leal MC, Pereira APE, Domingues RMSM, Theme Filha MM, Dias MAB, Nakamura-Pereira M, et al. Intervenções obstétricas durante o trabalho de parto e parto em mulheres brasileiras de risco habitual. Cad Saúde Pública [Internet]. 2014 [citado 2015 nov. 11];30 Supl.1:S17-32. Disponível em: http://www.scielosp.org/pdf/csp/v30s1/0102-311X-csp-30-s1-0017.pdf 